\title{
A holistic interdisciplinary approach towards environmental justice and youth empowerment
}

\begin{tabular}{|c|c|}
\hline \multicolumn{2}{|c|}{$\begin{array}{l}\text { Author: } \\
\text { Marichen A. van der } \\
\text { Westhuizen }^{1}\end{array}$} \\
\hline \multicolumn{2}{|c|}{$\begin{array}{l}\text { Affiliation: } \\
{ }^{1} \text { Department of Social Work, } \\
\text { Faculty of Community and } \\
\text { Health Sciences, University } \\
\text { of the Western Cape, Cape } \\
\text { Town, South Africa }\end{array}$} \\
\hline \multicolumn{2}{|c|}{$\begin{array}{l}\text { Corresponding author: } \\
\text { Marichen van der } \\
\text { Westhuizen, } \\
\text { marichenvdw@gmail.com }\end{array}$} \\
\hline \multicolumn{2}{|c|}{$\begin{array}{l}\text { Dates: } \\
\text { Received: } 22 \text { Mar. } 2021 \\
\text { Accepted: } 25 \text { May } 2021 \\
\text { Published: } 14 \text { July } 2021\end{array}$} \\
\hline \multicolumn{2}{|c|}{$\begin{array}{l}\text { How to cite this article: } \\
\text { Van der Westhuizen, M.A., } \\
2021 \text {, 'A holistic } \\
\text { interdisciplinary approach } \\
\text { towards environmental } \\
\text { justice and youth } \\
\text { empowerment', } \\
\text { HTS Teologiese Studies/ } \\
\text { Theological Studies } \\
\text { 77(2), a6640. https://doi. } \\
\text { org/10.4102/hts.v77i2.6640 }\end{array}$} \\
\hline \multicolumn{2}{|c|}{$\begin{array}{l}\text { Copyright: } \\
\text { @ 2021. The Authors } \\
\text { Licensee: AOSIS. This } \\
\text { is licensed under the } \\
\text { Creative Commons } \\
\text { Attribution License. }\end{array}$} \\
\hline \multicolumn{2}{|l|}{ Read online: } \\
\hline 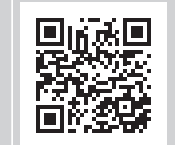 & $\begin{array}{l}\text { Scan this QR } \\
\text { code with your } \\
\text { smart phone or } \\
\text { mobile device } \\
\text { to read online. }\end{array}$ \\
\hline
\end{tabular}

South African youth is described as marginalised and vulnerable because of, amongst others, high unemployment rates, a lack of access to opportunities and environmental degradation that threatens their and future generations' well-being. Both social work and faith-based organisations place value on the empowerment of marginalised youth, as well as on the importance of participatory environmental initiatives. Practice guidelines to effectively empower youth in this regard are, however, lacking. This discussion was aimed at determining how environmental social work can take place in collaboration with faith-based organisations to contribute to both the empowerment of youth and environmental justice. A search of literature from 2010 onwards was conducted, focusing on the terms 'sustainable development', 'marginalised youth', 'environmental and/or green social work' and 'faith-based organisations'. Central themes were identified through a thematic analysis. Four central themes were identified for youth empowerment through an interdisciplinary approach to contribute to environmental justice, namely environmental responsibility, attitude, knowledge and concern. It was concluded that the potential of an interdisciplinary environmental approach may be based on collaboration and an openness to include a renewed change orientation where disciplines work together across boundaries in multiple spaces to support environmental change and youth empowerment simultaneously.

Contribution: The framework for collaborative initiatives may service as a guide to support marginalised youth to actively participate in social and environmental justice initiatives to contribute to their own and future generations' well-being.

Keywords: empowerment; environmental social work; faith-based organisations; holistic social work; interdisciplinary approach; sustainable development.

\section{Introduction}

The concern for environmental preservation stems from an increase in climate changes and natural disasters, as well as political and socio-economic instability. Klarin (2018:67) argued that humans endangered the survival of the Earth and that they now need to address this damage to ensure that future generations do not pay the price for the behaviour of earlier generations. This author describes development in terms of changing behaviours through knowledge and awareness and notes that sustainable development requires behaviours that will not only prevent environmental damage but also address the damage that was already done.

In this article, two global agendas to address environmental concerns and aimed at environmental change and social justice are discussed as a backdrop to a discussion of challenges experienced by South African youth and their relation to environmental issues. The importance of the inclusion of youth initiatives in sustainable development is discussed, followed by a description of environmental social work and how this relates to youth empowerment. Environmental social work from an ecological and holistic approach requires an interdisciplinary framework to support sustainable development. Focusing on interdisciplinary work, environmental social work in collaboration with faith-based organisations is explored. With this in mind, a framework for a holistic interdisciplinary approach towards environmental justice and youth empowerment is proposed as a conclusion.

\section{Environmental concerns}

Environmental concerns such as pollution, soil erosion, pesticide contamination, deforestation and declining animal and species populations (cf. Dunlap \& Jorgenson 2012:2) that were identified

Note: Special Collection: Youth, Faith, Climate Change and Environmental Consciousness: A Case for Sustainable Development, sub-edited by Jacques Beukes (University of Pretoria), Juliane Stork (Humboldt University) and Ignatius Swart (University of the Western Cape). 
in the 1970s are still existing, whilst new political, economic, social and technological advances in the 21st century add to these concerns. This calls for new strategies to address environmental concerns through sustainable development initiatives (Valavanidis 2019:1).

Often, environmental interventions are viewed as a concern of the natural sciences. However, the social sciences can and should play an important role to ensure a change in orientation amongst members of society with the aim to not only create awareness of the need for environmental preservation but also to develop knowledge and skills to ensure that they become active role players in environmental interventions. Rocha (2018:4) related this to the right to a healthy environment, whilst Lucas-Darby (2011:114) postulated that all citizens have a fundamental right and responsibility to protect the environment from harmful human activities. Vorster (2012:1) discussed human rights from a theological perspective and asserted that it has to do with the right to self-determination through choice. To further explore what these rights, choices and responsibilities would entail, two global agendas aimed at sustainable development, including environmental sustainability, are discussed in the following section.

\section{Global agendas to address environmental concerns}

Lombard (2015:486) asserted that both the Global Agenda for Social Work and Social Development (2012), hereafter referred to as the Global Agenda, and the United Nation's Agenda for Sustainable Development, referred to as the 2030 Agenda (United Nations 2015), responded to the need for environmental interventions, and both these agendas support the notion that sustainable development for the benefit of humanity requires crucial protection of the planet.

The emphasis on the inclusion of the environment in which people live in social work practice is emphasised in the Global Agenda (2012). Tasse (2014:283) asserted that this agenda calls for spaces where the profession and other disciplines, such as faith-based organisations in the case of this discussion, can debate on what is needed for sustainable development to take place. This, then, places an emphasis on interdisciplinary environmental work. Similarly, the 2030 Agenda (United Nations 2015:3) acknowledges a need for a people-centred plan of action to, amongst others, find ways to address those aspects that threaten humanity and the planet.

Lombard (2015:483) compared these two agendas and noted that both documents call for equality, tolerance and inclusion to ensure that the needs of vulnerable people can be met. In this article, the inclusion of vulnerable and marginalised youth in environmental issues is argued as an important part of social and environmental justice. It is argued that equality may be hampered by external constraints, such as a lack of access to resources or a threat to the sustainability of natural resources needed for human well-being. The empowerment of vulnerable and marginalised youth to become active participants in sustainable development initiatives supports the inclusion of the principles mentioned by Lombard (2015:483). Similarly, Dominelli (2014:338) draws a link between environmental degradation and the reinforcement of structural inequalities. This, then, requires a critical reflection on what is needed to create sustainable development to ensure a healthy environment in which people's needs can be met through practices of inclusion and equality. In support of this stance, Tasse (2014:283) argued for radical social change where the social service professions work together to challenge structures that threaten human well-being and the protection of the planet and to empower individuals and communities to find ways to contribute to sustainable development.

Aligned with the United Nations' 2030 Agenda for Sustainable Development and in order to promote environmental and community sustainability, the Global Agenda for Social Work and Social Development (Lombard 2015:486) identified goals 12-15 for sustainable environmental development, focusing on sustainable consumption and production patterns (Goal 12), action to combat climate change and its impacts (Goal 13), conservation of resources (Goal 14) and the promotion of sustainable use of ecosystems (Goal 15). The next subsection will further explore what would be needed for sustainable development to take place.

\section{Towards sustainable development}

Sustainable development has to do with how the future is seen in terms of what will be needed to ensure human and environmental well-being and what actions are needed to ensure this (Rocha 2018:3). The depletion of natural resources, environmental degradation and climate change challenge the quest for sustainable development (United Nations 2015). Whilst this has already an effect on human well-being, future generations will be even more exposed to the consequences of irresponsible attitudes and behaviours towards nature. This, then, calls for a critical exploration of how different disciplines can support and empower individuals, groups and communities to actively engage with environmental issues.

Valavanidis (2019:5) identified the protection of natural resources, biodiversity, sustainability and human health as top priorities for sustainable development initiatives. This author raises the concern that continued unsustainable economic growth leads to inevitable exhaustion of natural resources (Valavanidis 2019:12). Allen and Clouth (2012:15) referred to a green economy as a form of sustainable development that addresses social issues such as poverty and equity. With the focus on the conservation of natural resources and minimising pollution and production practices that do not harm the environment, the authors advise that green economy practices can contribute to sustainable development. Youths have an opportunity here to become active pioneers in the development of emerging renewable energy technologies through awareness raising and skills development initiatives. Sustainable development therefore does not only rely on the production of scientific evidence 
and political and economic responses but also on society to become aware of the need for sustainable development, to obtain knowledge about how they can contribute and respond to practices that endanger sustainable development.

Environmental and social change is required for sustainable development to take place. In this way, a link between environmental and social justice and sustainable development is drawn. Practices towards environmental and social change are to protect natural resources and to develop strategies to ensure an equal distribution of the Earth's resources whilst also ensuring that resources are not depleted. In this article, the empowerment of vulnerable and marginalised youth as social justice will be linked to environmental justice where they are empowered to become change agents to support sustainable development. To empower vulnerable and marginalised youth, one has to understand his or her plight.

\section{The plight of marginalised and vulnerable youth}

Globally, youth aged 19-34 years (World Health Organization [WHO] 2020) are viewed as at risk for being marginalised and vulnerable (Columbia Global Policy Initiative 2014:6). This is particularly true for South African youth (Department of Social Development 2013:30). Beukes and Van der Westhuizen (2018:2-3) mentioned three contributing factors to the vulnerability of South African youth as poverty, unemployment and exclusion. Further factors contributing to the marginalisation of South African youth include a lack of or inadequate skills development opportunities, high drop-out rates in schools and institutions of higher education, exposure to substance abuse, crime and violence and a general lack of inclusion in decision making that empowers them to engage with their own futures. The empowerment of youth has the potential to combat marginalisation and can lead to sustainable development in that they are being acknowledged as partners in social and economic change and development (National Youth Policy 2015:10-15). This article argues for the inclusion of vulnerable and marginalised groups in environmental initiatives. As a starting point, one has to consider youth's current responses to environmental issues.

\section{Youth responding to environmental concerns}

In 2018, a young Swedish activist, Greta Thurnberg, initiated the \#FridaysForFuture movement whereby youth protest every Friday against a lack of political and economic responses to environmental concerns by school striking. This movement also reached South Africa during 2019, when South African youth joined the FridaysForFuture South Africa movement, protesting against South Africa's stance on energy production. On 29 November 2019, they asked for a moratorium on new coal, gas, oil and mining licences, $100 \%$ renewable energy by 2030, a green new deal for South Africa and climate adaptation as a focus in educational practices in schools (Fridays for Future South Africa 2019). This points to South African youth becoming responsive to global initiatives. This article explores how youth can be empowered not only to voice concerns but also to become active participants in finding solutions for a green future.

\section{Key aspects to include in youth empowerment through environmental initiatives}

Working with youth towards environmental awareness and sustainable development requires an ecocentric focus, a change orientation, the inclusion of a variety of stakeholders who can support interventions and the development of knowledge and skills of what is needed for youth in a specific context to become active in preserving the planet whilst engaging in their own development (Ramsay \& Boddy 2016:13). Janmaimool and Chudech (2020:3) asserted that the catastrophic environmental events and the impact thereof on human well-being and natural ecosystems can be used as a motivation to raise environmental awareness and concern amongst youth to develop a greater individual sense of environmental responsibility. This, then, may lead to active engagement with and participation in sustainable development initiatives that will contribute to the development of their own potential and the protection of natural resources for future generations. In this way, they can potentially experience social justice and contribute to both environmental and social justice. This viewpoint is supported by Borst, Mason and Shires (2017:28) who argued for youth employment initiatives that are combined with environmental initiatives. Such initiatives are aimed at creating opportunities to encourage awareness and ownership of actions to preserve the planet, provide them with skills to become self-reliant and in this way contribute to sustainable development towards the well-being of youth and the planet.

The National Youth Policy (2015:8-10) emphasised the need to support youth to develop their strengths and potential to be able to contribute to their own development, as well as that of the country. Through participation in environmental projects, youth could be empowered to become aware of the importance of the Earth as a primary resource for the future, develop skills to address unemployment, contribute to a green economy, critically engage with social and environmental injustices and engage with moral and spiritual developments that are in line with Ubuntu. Ubuntu, in the South African context, has to do with humanity towards others (Mboti 2015:126). Through participation in environmental initiatives, youth can practice Ubuntu to preserve the planet and its resources for the future generations. Social work that aims to encourage youth participation and empowerment and that focuses on a holistic interdisciplinary approach towards environmental justice will be presented in the following section.

\section{Environmental social work}

Rocha (2018:2) asked the following two questions: How does social work respond to the social and environmental realities of communities that require actions towards sustainable development? How can social work contribute to the stimulation of actions to mobilise and empower communities through socio-environmental practices? These two questions emphasise that responses should emanate in actions. 


\section{Social work's response to the environment}

Ramsay and Boddy (2016:1) discussed the inclusion of environmental issues that threaten the Earth and humankind in social work and note that this is referred to as green, ecological or environmental social work; all acknowledging the link between environmental work and sustainable development. For the purpose of this article, the term environmental social work will be used. Dominelli and Ku's (2017:11) description of social work practices that focus on the environment guided this discussion. According to these authors, it is a holistic approach that focuses on relationships between people, between people and nature and between people and change agents within communities. These relationships should lead to the right to choose and the empowerment to be a change agent (cf. Vorster 2012:1).

It also includes addressing structural inequalities that lead to unequal distribution of resources. Whilst environmental social work will include working with individuals, groups and communities towards change in the relationships between people and the environment, it also requires an activist approach to address socio-political and economic forces that lead to environmental degradation (Dominelli \& $\mathrm{Ku}$ 2017:11). Figure 1 illustrates environmental social work from a holistic ecological approach in terms of the different layers in which individuals function.

Environmental social work with youth, according to the above framework, will focus on the development of attitudes, knowledge and skills that relate to environmental issues in their communities and include relationships that can contribute to empowerment and sustainable development. This requires the inclusion of stakeholders related to youth work and environmental issues to support an interdisciplinary holistic ecological approach.

\section{An interdisciplinary holistic ecological approach to sustainable development}

Dominelli (2014:339) argued that if one is concerned about social injustice, it should also include a concern about environmental injustice. As an example, social injustice leads to, amongst others, industrial waste being dumped on poor

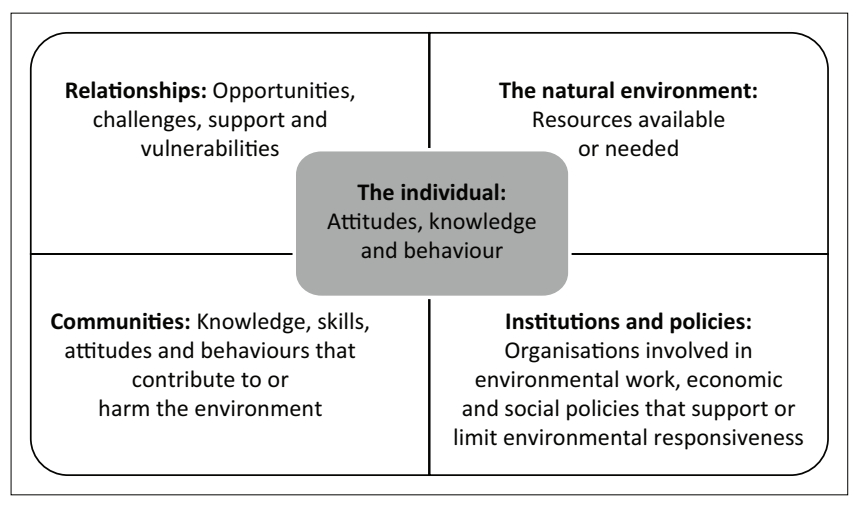

Source: Adapted from Scott, V. \& Wolfe, S.M., 2015, Community psychology foundations for practice, Sage, Thousand Oaks, CA.

FIGURE 1: Environmental social work. communities, which in turn affects food production and physical health. As such, Ungar (2002:481) introduced environmental justice as a principle. Dominelli (2014:339) distinguished between environmental injustice and justice. The author refers to environmental injustice as unequal distribution of the Earth's resources to meet human needs that include a failure to ensure social justice in human well-being as well as the preservation of the planet. Environmental justice has to do with organising and mobilising communities to protect the Earth and to ensure that resources are used wisely and equitably. Drawing a link between environmental and social injustices, Jones (2009:19) asserted that environmental work is more than just recycling. In addition to not throwing things away that are not needed or wanted, it also has to do with reclaiming those communities that are forgotten. Collaborative interdisciplinary empowerment strategies can contribute to members of a community taking ownership of their environment and choosing to become change agents and in this way also address socio-economic inequalities.

Previous studies in social work highlighted the need to include environmental social work practices in the curriculum and in practice (Jones 2013:213; Raniga \& Zelnick 2014:393). From an ecological approach, environmental social work must align practices with community initiatives to integrate environmental and human dimensions (Lombard 2015:487). The Person in Environment perspective supports the ecological approach as it acknowledges that sustainable development requires a consideration of the relationship between people and their behaviour towards the environment (Rocha 2018:4). In line with the above description of environmental social work, a holistic ecological approach will focus on interventions to address environmental issues on micro-, meso- and macro-levels in communities. This includes working in collaboration with other interested parties in the communities, such as faith-based organisations. As such, Rocha (2018:14) argued that environmental social work is framed within an interdisciplinary approach. Stakeholders and role players in communities who are concerned about sustainable development and social justice include environmental experts and scientists, as well as social change agents such as faith-based organisations, social workers, community development practitioners and nongovernmental initiatives. For this discussion, collaboration and interdisciplinary environmental youth work focus on social work and faith-based community organisations.

\section{Social work and faith-based organisations}

This article focuses on interdisciplinary work between the disciplines of social work and theology or religious studies. Interdisciplinary work will refer to interventions by social work organisations and faith-based organisations. In South Africa, faith-based organisations have played an important role in the anti-apartheid struggle, pointing to a historical position of actively promoting change. For this article, faith-based organisations will refer to churches and congregations, as well as organisations that represent faithbased organisations in communities. These organisations 
may include faith-based representative organisations, charitable or development organisations, socio-political and missionary organisations (Bowers du Toi 2017:2). Horwitz (2019:1), however, asserts that the role of faith-based organisations as change agents in present times has become less noticeable. This author argues that the potential of interventions by faith-based organisations in collaboration with other change agents in communities, including social workers, can play an important role to empower communities to create and sustain change. Similarly, Van der Westhuizen and Swart (2015:744) reported a link between services by faith-based organisations and sustainable development that address poverty, unemployment and social injustices and noted that faith-based organisations often collaborate with social workers in secular non-governmental organisations.

Collaborative environmental work between social workers and faith-based organisations to address social and environmental injustice provides opportunities for new insights, knowledge and skills to find creative solutions that are in line with the needs of the specific community, whilst resources are shared to increase capacity (Dominelli 2012:106; Horwitz 2019:5; Rambaree 2013:265). In addition, collaborative work does not only include other disciplines but also cultural and spiritual leaders, activists and community members (Horwitz 2019:1; Lysack 2012:263).

Initiatives by social workers and faith-based organisations share certain focus areas. Social work is concerned with, amongst others, social change and development, collective responsibility and the empowerment of people (International Federation of Social Workers 2014). Faith-based organisations aim to support and care for vulnerable and marginalised individuals and groups, alleviate suffering, empower them with knowledge and skills to contribute to their own wellbeing and enable them to care for others (Beukes \& Van der Westhuizen 2018:2). Interdisciplinary environmental work with youth will therefore focus on addressing their vulnerabilities through knowledge and skill development that will empower them to not only reach their own potential and address their own needs but also to contribute to society and their environment.

Making use of the ecological framework for environmental social work, this article concludes with a proposed framework for interdisciplinary work with faith-based organisations to support environmental justice and youth empowerment to contribute to sustainable development.

\section{A proposed framework for a holistic interdisciplinary approach towards environmental justice and youth empowerment}

In the 21st century, the environmental crisis has become a major concern regarding how this will impact future generations. Dominelli (2014:338) argued that, whilst many natural disasters stem from human practices and industrialisation processes, society has taken nature for granted. In line with this viewpoint, Rocha (2018:2) asserted that environmental and social problems are interrelated and that we need to acknowledge how environmental issues are caused by industrialisation and lifestyles, whilst the vulnerable communities who do not share in the advantages often pay the highest price. To address this, changes in the way we interact with nature are needed. From an interdisciplinary approach, it is argued that collaborative work can address attitudes, knowledge and skills in the way vulnerable and marginalised groups interact with their environments whilst also empowering these groups to address their own needs, reach their potential and contribute to sustainable development practices. In support of this argument and focusing on youth to be included in environmental social work, Ramsay and Boddy (2016:10) asserted that raising awareness alone will not be enough to create sustainable change. Rather, it is important to develop skills to encourage the reduction of environmental footprints whilst empowering them to care for themselves through environmental work (Dominelli 2012:211).

The role of social workers to build resilience amongst community members, including youth, to ensure sustainable change and development is described by Dominelli and $\mathrm{Ku}$ (2017:16) in terms of empowerment initiatives. This may be focused on awareness-raising and encouraging conversations to identify those practices in a society that harms the environment, lobbying for structural and economic changes that include the introduction of technologies and the sharing of resources and mobilising communities to define and practice green living (Dominelli \& Ku 2017:16).

The role of faith-based organisations is described by Horwitz (2019:2-5) who advise six key components to guide transformative and sustainable interventions, namely: (1) creating spaces and conversations for personal transformation of individuals, (2) choosing a specific area to contribute to, (3) building on strengths and working around weaknesses, (4) encouraging Ubuntu practices of understanding and caring for each other, (5) collaborating with others to share resources and (6) bridging divides to ensure equality and equity.

\section{Interdisciplinary environmental work}

To explore what interdisciplinary environmental work would mean in practice, as well as the knowledge and skills needed, it must be noted that little has been written about this topic (Ramsay \& Boddy 2016:1). Ramsay and Boddy (2016:6-10) identified attributes through a content analysis of current descriptions of environmental work and describes this in three main themes that were used to direct the proposed framework for environmental social work in collaboration with faithbased organisations presented in the following section.

\section{Openness to different values and ways of being or doing}

Informed by relevant theories and values of social justice and equality, a shift is needed in practice to incorporate the natural environment. Practices must 
acknowledge and include spirituality and indigenous cultures to follow a bottom-up approach to sustainable development. As such, environmental social work should be included in curricula and not be seen as an add-on.

Within the proposed framework, it is recommended that the social work curriculum includes theories, perspectives and approaches related to environmental work to support youth empowerment. In addition, a focus on collaborative work should empower students to identify key role players in the community, as well as to build collaborative partnerships. In this way, students are equipped with an understanding, knowledge and skills to collaborate interprofessionally and with communities to contribute to environmental work that supports empowerment initiatives as part of social justice and sustainable development as part of environmental justice. Interprofessional work supports the inclusion of a variety of role players to contribute to the development of sustainable development initiatives whilst also empowering marginalised and vulnerable youth. This will include the following key functional elements to be included in the social work curriculum: (1) identifying existing knowledge, skills and practice examples; (2) further developing a knowledge base that can contribute to research-based and a bottom-up approach to environmental social work; (3) raising awareness amongst social work students of the need to engage with individuals, groups and communities regarding their relationship with nature as a crucial component of sustainable development and (4) identifying skills needed to empower youth through environmental initiatives to be included in learning and teaching practices.

\section{Adopt a renewed change orientation}

Social workers, in their efforts to contribute to social justice, should critique oppression and domination, including those structures that do harm to the environment without considering the people who will be affected by it. In this way, social workers are obligated to create awareness in communities so that society can voice their concerns and become active partners in protecting the planet so as to contribute to sustainable development.

Environmental issues that pose a threat for communities and society should be explored to not only raise awareness within these communities but also to encourage actions to advocate against damaging practices and for positive and sustainable change and development. Functional elements include (1) developing environmental networks to include all relevant stakeholders; (2) including vulnerable and marginalised youth, exploring threats to sustainable development; (3) exploring opportunities where youth can become active participants in environmental change and (4) raising awareness and campaigning for change in relationships between people and their environment.

\section{Work across boundaries and in multiple spaces}

From an ecological perspective, social workers work with individuals, families and communities, include stakeholders in interventions. This requires the ability to collaborate with other disciplines to strengthen the agenda to support sustainable development through the inclusion of environmental interventions.

As part of both an openness to adapt the way we think and do, as well as a change orientation, collaboration should contribute to a shared knowledge base, skills and resources. Collaboration, from a social justice stance, should include youth as key stakeholders in actions towards environmental justice. Functional elements include the following (1) including youth as active participants in the development of environmental initiatives within their communities, nationally and globally; (2) sharing of existing knowledge, skills and practice examples; (3) developing a shared knowledge base; (4) sharing existing resources and (5) identifying skills needed to empower youth through environmental initiatives, which can also provide them with employment opportunities.

The above attributes were used to explore the key aspects to be included in a framework for environmental justice and youth empowerment.

\section{Environmental justice through youth empowerment}

Janmaimool and Chudech (2020:4-6) identified key aspects to address to empower youth to actively become part of environmental work, which can frame how youth are empowered through their inclusion in environmental initiatives. These aspects may be included in an interdisciplinary approach by environmental social workers and faith-based organisations as discussed in the following subsections.

\section{Environmental responsibility}

Environmental justice takes place when youth are empowered through a sense of personal obligation towards the environment and responsibility to take action to contribute to sustainable development. This requires engagement with youth to identify those environmental concerns in their communities where they can contribute to change not only their own but also the community and authorities' orientation that will support sustainable development.

\section{Environmental attitude}

Beliefs, affects and behavioural intentions regarding responses to the environment include the relationship between humanity and the natural environment, environmental values about the significance of natural resources and environmental sensitivity to recognise the seriousness of environmental problems and how humans can contribute to the damage as well as to the preservation of the Earth. Through a change in attitude, youth can become activists to encourage political and economic accountability. It should, however, not only focus on 
expecting power structures' responses to environmental issues. Environmental attitudes should lead to a change of behaviour towards the environment and to responsiveness to those aspects that threaten natural resources.

\section{Environmental knowledge}

Subjective knowledge has to do with perceptions and understanding of the role and function of nature in terms of sustainability. Objective knowledge refers to knowledge about what damages the environment and what can be done to avoid or address the damage. Working with youth, it is important to create spaces where objective knowledge can be explored and compared to subjective knowledge. This is aimed at supporting youth to identify their concerns and options for them to respond to environmental concerns.

\section{Environmental concern}

The development of a concern about environmental problems and dangers to the Earth's ecosystems and to the sustainability of nature should motivate a person to become active towards sustainable development initiatives. It has to do with the development of consciousness towards environmental and ecological problems that lead to environmental problemsolving actions. Environmental knowledge should inform environmental attitudes and responsibility with the outcome of a concern that informs solution-focused initiatives. Youth should take ownership for environmental problem solving to contribute to their own and future generations' well-being.

\section{Conclusion}

The above discussion supports a framework where different disciplines can follow a holistic approach to empower youth and contribute to sustainable development. The common ground that informs the collaboration between the environmental social work and faith-based organisation studies is that of an eco-focused approach to sustainable development. This eco-focused approach is informed by subjective and objective knowledge and an attitude of mutual concern and responsibility that leads to collaborative problem solving. The interdisciplinary collaboration is aimed at finding solutions for ecological issues that threaten the wellbeing of a community or society and therefore supports a change orientation to the way we engage with nature. The interdisciplinary team is open to change thoughts and actions and to support the development of skills needed for environmental issues to be addressed successfully. The aims of the collaborative initiatives may include the encouragement and empowerment of (1) a society that responds to environmental issues and advocates for environmental-friendly practices (2) local, national and global initiatives to address harm to the environment; (3) preservation of natural resources in communities; (4) changes in the relationship between humans and the environment; (5) youth empowerment through active participation in social and environmental justice initiatives and (6) youth having access to opportunities in a green economy.
In the above proposed framework, an ecocentric focus will ensure that environmental initiatives will aim to create spaces where youth can become active role players in environmental and social justice practices. Interdisciplinary work between social work and faithbased service providers will lead to collaborations where knowledge, skills and resources will be shared to empower youth with objective and subjective environmental knowledge and environmental attitudes, concerns and responsibilities that will support them to become change agents who contribute to sustainable development. Through including them in problem-solving and solutionfocused discussions, it is envisaged that they will lead environmental initiatives with an openness to change of thoughts and actions to transform how the next generation will engage with nature and natural resources. The role of both social work and faith-based organisations will be to provide youth with opportunities to develop skills needed for environmental initiatives.

This article looked at how social work can respond to environmental concerns, as directed by the Global Agenda (2012). However, through a holistic interdisciplinary approach, this proposed framework aims to support interdisciplinary actions that will empower youth to lead environmentally and socially justice initiatives and to advocate for political and economic change and accountability that will change how humanity relates to natural resources. The emphasis on empowering youth to become active role players can contribute to global sustainable development initiatives as their empowerment will inform future social and environmental practices.

\section{Acknowledgements Competing interests}

The author declares that she has no financial or personal relationships that may have inappropriately influenced her in writing this article.

\section{Author's contributions}

M.v.d.W. is the sole author of this article.

\section{Ethical considerations}

This article followed all ethical standards for research without direct contact with human or animal subjects.

\section{Funding information}

This research received no specific grant from any funding agency in the public, commercial or not-for-profit sectors.

\section{Data availability}

Data sharing is not applicable to this article as no new data were created or analysed in this study. 


\section{Disclaimer}

The views and opinions expressed in this article are those of the author and do not necessarily reflect the official policy or position of any affiliated agency of the author.

\section{References}

Allen, C. \& Clouth, S., 2012, A guidebook to the green economy Issue 1: Green economy, green growth, and low-carbon development - History, definitions and a guide to recent publications, United Nations Division for Sustainable Development, New York, NY.

Beukes, J. \& Van der Westhuizen, M., 2018, 'Moving from faith-based concerns to demarginalizing youths through the Circle of Courage', HTS Teologiese Studies/ Theological Studies 74(3), a5013. https://doi.org/10.4102/hts.v74i3.5013

Borst, A., Mason, L.R. \& Shires, M.K., 2017, 'Youth and the Green Economy', in M. Rinkel \& M. Powers (eds.), Social work promoting community and environmental sustainability: A workbook for global social workers and educators, pp. 28-34, The International Federation of Social Workers, Berne.

Bowers du Toit, N.F., 2017, 'Meeting the challenge of poverty and inequality? "Hindrances and helps" with regard to congregational mobilisation in South Africa', HTS Theological Studies 73(2), a3836. https://doi.org/10.4102/hts. Africa', HTS
v73i2.3836

Columbia Global Policy Initiative, 2014, Overcoming youth marginalization conference report and policy recommendations, Columbia Global Policy Initiative and the Office of the United Nations Secretary-General's Envoy on Youth, New York, NY.

Department of Social Development, 2013, Framework for social welfare services, Department of Social Development, Pretoria.

Dominelli, L., 2012, 'Mind the gap: Built infrastructures, sustainable caring relations, and resilient communities in extreme weather events', Australian Social Work 66(2), 204-217. https://doi.org/10.1080/0312407X.2012.708764

Dominelli, L., 2014, 'Promoting environmental justice through green social work practice: A key challenge for practitioners and educators', International Social Work 57(4), 338-345. https://doi.org/10.1177\%2F0020872814524968

Dominelli, L. \& Ku, H., 2017, 'Green social work and its implications for social development in China', Journal of Social Work 10(1), 3-22. https://doi.org/10.108 0/17525098.2017.1300338

Dunlap, R.A. \& Jorgenson, A.K., 2012, 'Environmental problems', in G. Ritzer (ed.) The Wiley-Blackwell encyclopaedia of globalization, 1st edn., pp. 1-8, Blackwel Publishing Ltd, Oxford.

Fridays for Future South Africa, 2019, viewed 22 November 2020, from https:// fridaysforfuture.org.za/.

Global Agenda for Social Work and Social Development, 2012, Collaboration between IASSW, IFSW \& ICSW, viewed 02 November 2020, from https://www. socialdialogue.online/SDpdf/VOL.14.pdf.

Horwitz, D., 2019, Faith-based organisations: Hands-on experience learning, viewed 03 November 2020, from https://dgmt.co.za/wp-content/uploads/2019/11/ Faith-based-Organisations-Opp-3-Single-FinalDigital.pdf.

International Federation of Social Workers, 2014, Global definition of social work viewed 03 November 2020, from https://www.ifsw.org/what-is-social-work/ global-definition-of-social-work/.

Janmaimool, P. \& Chudech, S., 2020, 'Effect of domestic and global environmental events on environmental concern and environmental responsibility amon university students', Sustainability 12, 1610. https://doi.org/10.3390/su12041610
Jones, P., 2013, 'Transforming the curriculum. Social work education and ecological consciousness', in M. Gray, J. Coates \& T. Hetherington (eds.), Environmental social work, p. 213, Routledge, New York, NY.

Jones, V., 2009, The green collar economy: How one solution can fix our two biggest problems, HarperCollins Publishers, New York, NY.

Klarin, T., 2018, 'The concept of sustainable development: From its beginning to the contemporary issues', Zagreb International Review of Economics \& Business 21(1) 67-94. https://doi.org/10.2478/zireb-2018-0005

Lombard, A., 2015, 'Global agenda for social work and social development: A path toward sustainable social work', Social Work/Maatskaplike Werk 51(1), 482-499. https://doi.org/10.15270/51-4-462

Lucas-Darby, E.T., 2011, 'The new color is green: Social work practice and servicelearning', Advances in Social Work 12(1), 113-125. https://doi.org/10.18060/1340

Lysack, M., 2012, 'Building capacity for environmental engagement and leadership: An ecosocial work perspective', International Journal of Social Welfare 21(3) 260-269. https://doi.org/10.1111/j.1468-2397.2011.00854.x

Mboti, N., 2015, 'May the real Ubuntu please stand up?', Journal of Media Ethics 30(2), 125-147. https://doi.org/10.1080/23736992.2015.1020380

National Youth Policy 2015-2020, 2015, We are generation2020. We don't want a hand-out, we want a hand up!, National Youth Development Agency, Johannesburg.

Rambaree, K., 2013, 'Social work and sustainable development: Local voices from Mauritius', Australian Social Work 66(2), 261-76. https://doi.org/10.1080/03124 07X.2013.784793

Ramsay, S. \& Boddy, B., 2016, 'Environmental social work: A concept analysis', British Journal of Social Work 0, 1-19. https://doi.org/10.1093/bjsw/bcw078

Raniga, T. \& Zelnick, J., 2014, 'Social policy education for change: South African student perspectives on the Global Agenda for Social Work and Social Development', Special Issue of International Social Work 57(4), 386-397. https:// Development', Special Issue of International
doi.org/10.1177\%2F0020872814527634

Rocha, H.B., 2018, 'Social work practices and the ecological sustainability of socially vulnerable communities', Sustainability 10, 1312. https://doi.org/10.3390/ su10051312

Scott, V. \& Wolfe, S.M., 2015, Community psychology foundations for practice, Sage, Thousand Oaks, CA.

Tasse, A., 2014, 'Editorial. Special Issue', International Social Work 57(4), 383-384. https://doi.org/10.1177/0020872814533875

Ungar, M., 2002, 'A deeper, more social ecological social work practice', Social Services Review 76, 480-97. https://doi.org/10.1086/341185

United Nations, 2015, Transforming our world: The 2030 Agenda for Sustainable Development, Advanced unedited version, Finalised text for adoption, viewed 30 October 2020, from https://sustainabledevelopment.un.org/post2015/transformingourworld.

Valavanidis, A., 2019, 'Current environmental issues and emerging global challenges in the 21st century for environmental protection and sustainable development', in the 21st century for environmental protection and sustainable development',
Scientific Reviews 1-53, viewed 04 January 2021, from http://chem-tox-ecotox. Scientific Reviews 1-53, viewed 04 January 2021, from http://chem-tox-ecotox.
org/wp-content/uploads/2019/12/EMERGING-ENVIRONMENTAL-ISSUESorg/wp-content/up

Van der Westhuizen, M. \& Swart, I., 2015, 'The struggle against poverty, unemployment and social injustice in present-day South Africa: Exploring the involvement of the and social injustice in present-day South Africa: Exploring the involvement of the Dutch Reformed Church at congregational level, Stellenbosch
1(2), 731-759. https://doi.org/10.17570/stj.2015.v1n2.a35

Vorster, N., 2012, 'A theological perspective on human dignity, equality and freedom', Verbum et Ecclesia 33(1), 1-6. https://doi.org/10.4102/ve.v33i1.719

World Health Organization (WHO), 2020, Substance abuse, viewed 20 November 2020, from https://www.who.int/topics/substance abuse/en/. 